\title{
MODERN CONSERVATISM AS A WORLD PERCEPTION AND POLITICAL MOVEMENT: THE CASE OF AMERICAN NEOCONS AND PALEOCONS
}

Conservatism originated in definite historical conditions to counteract the modernization process in the countries of Western Europe. In conditions of rapid and basic changes in different spheres of life, a special aspiration of a human being to maintain the state of things became a basis for establishing a definite ideological system for some sections of traditional public. At first, it originated on the basis of denying the new and restoring the old (England, France).

The conservatism of that period was becoming identical with traditionalism and was regressive in its essence. However, it lasted no longer in Europe. When it was clear that progress was inevitable, aspirations to get used to it and find a special place in the changing world aroused. They served a basis for the classical conservatism, whose Motherland was England of the 19th century (Gelernter 2005: 16 - 24). In future it has found its deep theoretical basing in works of German politologists.

In the middle of the last century a tangible activation of political conservatism was observed. New powerful political conservative parties occurred on the political arena in Western Europe (Germany, Italy, and France). Unlike the conservators of the past, they managed to elaborate their special concepts of progress and restore their countries basing on them.

In the USA, the conservative political movements of the neo-conservators (neocons) and paleo-conservators (paleocons) became one of the main factors of the country's ideological and political life during the last decade of $20^{\text {th }}$ Century and first years of our Century. In this paper we shall discuss the main directions of political activities of Neocons and Paleocons. For carrying out this task it is essential to emphasize that modern conservatism is not just a political phenomenon; it is of much more complicated and multi-layered nature. It is based on a definite type of world perception and activity of a human being of our days, which is displayed in the public-and-political and spiritual spheres, as well as in everyday life. Recently a group of American specialists (J. Jost, J. Glazer and others) have made public the results of their years-long research testifying to the fact that there are common features characteristic of a "conservative person" even at a psychological level (Jost, Glaser, Kruglanski, Sulloway 2003: 339-375). It should be noted that here the question is general tendency, and not their display in various countries, which, of course, may differ from each other.

This perception of the world is based on three, at the first sight, contradicting to each other basic provisions:

a) Belief in the God and his commandments, which means, in morality;

b) The specific nature of thinking, mistrust in abstractions;

c) Preference of the perennial to the transitory.

A person perceiving the world in a conservative way reveal them correlated, it conditions his attitude to the external world. The differences between such persons depend on the mutual relations of these basic provisions. In some cases, the first provision is considered the first and foremost, in other cases, these are the third or the second ones.

Here is a noteworthy example: Hans Zeiger, one of the prominent relatively young persons of modern American conservatism writes: "I am a 
conservative because I believe in God ... and because I believe we must work within the framework of human nature to address realistic issues of order and liberty" (Zeiger 2003). Another American famous conservator thinker Russell Kirk in his well-known work on main principles of conservative thought notes that conservative person is that considers the perennial more pleasant than the Chaos (Kirk - http://www.kirkcenter.org/ index.php/detail/ten-conservative-principles/).

Professor John Kekes is one of the most original and influential conservative authors. He is defining conservatism as "political morality" (Kekes 1997: 351).

When considering the general image of a "conservative person," one can arrive at a conclusion that he perceive the reality as an hierarchic order established by the God since the beginning of time, which is fair in the main and provides the person observing the God's commandments with his special place. For this kind of person it is obvious, that in social life exists an order, which is separate from human will and "is to be discovered, not created or imposed by conscious human behavior" (Waligorski 1990: 8).

That is why, such person perceives any changes in this order over-sensitively if they do not proceed from its internal appropriateness. When a conservative person deals with external world, he, perceiving the reality as a community of specific events and phenomena, tries not to exceed the frameworks of visible horizon in its activity and keeps aside of what has a contemplative and hypothetical nature, in his opinion. Abstract thoughts are strange to him.

The peculiarity of a conservative person emerges in perception of the stream of time. He perceives the present as the last haven of the past and not the starting point of the future. So, he compares the present with the past and does not form an abstract image of the future to compare it with the present. For him, the past coexists with the present and becomes apparent in the form of precepts. That it why, traditional values have an important place in his world outlook.

The perception of history by a conservator is accounted for by the prevalence of spatial criteria. He tries to bring the general appropriateness of the stream of history to the changes in a specific space. In general, he appreciates higher what is less subjected to changes in the course of history i.e. first of all, the land history develops on.

Everyday consciousness, as well as some politologists, equates conservatory way of thinking and traditionalism. However, it is not so in reality. Modern conservatism is broader and deeper, and adherence to traditional value is an important but just one of its layers. Traditionalism unlike conservatism originated with origination of humankind and had an important regulating role. It was a simple counteraction against some external stimuli. The origination of conservatism supposed a high development level of humankind, in particular, complicated social sections and expressed deliberate interests of a definite section. Conservatism is an ideological system, with traditionalism being one of its elements. Even an inflexible revolutionary can be devoted to traditions in his personal life.

On the whole, it is not humble approaches to the changes in social life that are characteristic of the modern conservatism, but the aspiration to commensurate them with specific demands of the situation. It reflects the reality of American conservatism too. The last ten years of the $20^{\text {th }}$ century were significant with important moves in the public and ideological life of the USA. Communism, which had been perceived as the main enemy of American system of values for dozens of years, stopped very quickly displaying any danger after the Soviet Union and its satellites lost the "cold war." The defeat of the communistic ideology and political system was interpreted in the U.S. intellectual circles, first of all, as an unprecedented victory of liberal ideas. A new rise of liberalism as an ideological-and-political current 
was registered, which prevailed over conservatism for some period of time. The victory of the candidate representing the Democratic party Bill Clinton in the presidential election in 1992 was a result and, at the same time, the impetus of this atmosphere.

While a large group of liberals was drawn into the governmental system exerting all their efforts to spread liberal ideas and the methods of economy and government in the former communist countries, at the same time making the former Yugoslavia "calm and stable," conservatives, as it was characteristic to the people with such way of thinking, at first tried to understand and interpret the reality, and only then to act.

The anti-communist conservatives tried to find a new ideological target, which would replace communism, while "traditional" conservatives were engaged in search of ways to counterbalance the amazing victory of liberalists.

The works by specialists in social science Francis Fukuyama and Samuel Huntington having conservative orientation were published in that period of time and very soon became famous worldwide. These works reflected the frames of mind and the perceptions popular with American conservative circles which were often alternative and event contradicting to each other.

Deeply impressed with the defeat of communism and widely spread democratic values, the first one announced the end of the idealized "classic" history based on confrontation and the beginning of new "ideal times" whose decisive factor would be the prevalence of western democracy on the Earth (Fukuyama 1992: 418).

Meanwhile, basing on similar basic provisions, the second one arrived to opposite conclusions: according to S. Huntington, ideological confrontation will be replaced with a confrontation between different civilizations (Huntington 1996: 367).

The period of theoretical search by conservatives came to an end in the middle of 1990s, and they intensified their political activity. Due to their support, in 1994 the Republican Party won an important victory in the elections and took the Congress under its control. In conditions of acute ideological disputes in conservative circles, two groupings were brought to the forefront. During the following ten years, there groupings took a central role in the American conservative circles.

The strongest and the most experienced and, as it turned out later, the politically smartest of these two groupings, was, undoubtedly, the grouping of new conservatives (neo-conservatives) or, as they were called in short, neocons. When young, several representatives of the elder generation of this grouping had left views and supported the American Trotskyist Movement. But, later, supporting anti-communistic and conservative views they took a significant role in the country's political-and-ideological life under President Reagan. Among them, of course, it is necessary to mention Irving Kristol, who is considered the "godfather" of neocons. The latter published a collection of the articles he had written during several dozens of years entitled "Neoconservatism. The Autobiography of An Idea" in 1999.

Following the elders, representatives of younger generation of neocons even in American conditions were known by their radical anti-communism. Unlike "old people," they have rather quickly made their mind after the collapse of communism, and made the idea of the necessity of establishing USA's absolute prevalence in the world the major topic of their ideological propaganda. The leader of "young" neocons is Irving Kristol's son, William Kristol, and the Weekly Standard during the period published by him is considered the most important one on neo-conservatism.

In 1997, William Kristol jointly with a group of like-minders, including the former intelligence officer Bruce Jackson who had been in Armenia for many times, founded an Analytical Center 
with a pompous name "The Project for the New American Century" (PNAC). It pursued a goal to influence the foreign policy of Clinton's Administration through letters, public and other speeches or analytical materials, as neocons considered this policy apprehensive and not suiting the American power and they wanted to make it more decisive.

This center operates by present. Many famous representatives of the left wing of the American elite, who share the views of neocons, participate in the center's work. In particular, the PNAC not only has supported the policy of Bushjunior's Administration in respect to Iraq, but also justified it, motivating its approach by the necessity of securing USA's ruling role in the world.

After victory of G.Bush-junior in the presidential elections of 2000, neocons took advantage of the personal close ties with the newly elected President's family and the Vice President (for example, Jeb Bush, the President's brother, closely cooperates with the PNAC) and were actively drawn into the planning and implementation of the republican administration's foreign policy. Their representatives took important posts at Pentagon and the Department of State, as well as at the staffs of the country's President and Vice President. According to the American press, President Bush was strongly influenced by neocons.

Under the pressure of neocons, America's foreign policy has obtained a clearly displayed imperialistic orientation during the last years. They think that America as the only super power in the world at present can dictate its will to the whole world, including, to its allies and the UN.

In essence, neocons' ideologists brought forward a concept of the USA's development into an Empire and establishment of an individual governance of this Empire. Meanwhile, their companions-in-arms holding offices at high circles of government began practicing this concept under the screen of struggle against terrorism and contribution to establishing democracy in the world.
In the way towards implementation of this concept, the USA unleashed war against Iraq, worsened its relations with a number of important allies, and became an enemy of the Muslim world and especially of Arab states, as it unilaterally supported Israel in the Palestinian-Israeli conflict. USA's image in the world acquired clearly reflected negative colors.

It would not be superfluous to say that Jews, both Israelites and Christians, make up a great number among neocons. Probably, their unreserved assistance to Israel in the international arena as well as the close cooperation with the Jewish lobby in the USA is mainly accounted for by this. Several of them, as, for example, the former highranking official of the Defense Ministry and the former head of the authoritative Council for Defense Policy, Richard Pearl, were known in the corridors of power in Washington as Turkey's devoted friends.

Representatives of another authoritative conservative grouping in contrast with new conservatives are called old conservatives (paleoconservatives) or, in short, paleocons. The most famous figure of them is Pat Buchanan considered the leader of the grouping. As a talented orator, he has become famous by his speeches for maintenance of American traditional way of living and world perception, levering harsh criticism at all the deviations from them and innovations. Unlike neocons, he failed to enlist support of the Republican party, that is why, he came out as an independent MP during the presidential elections in 1990s, and in 2000 he even made an attempt to establish a separate conservative party. One of the eminent persons of the paleocons is publisher of The American Conservative periodical, Taki Theodoracopulos.

Paleocons consider themselves the followers of the traditions of the "classical" American conservatism, and accuse neocons of betrayal of conservative values. Pat Buchanan, for instance, thinks that the conservative movement in Ameri- 
can has been "hijacked" by neoconservatives (Joiner Sep 1, 2002).

Having at their disposal rather great material and spiritual resources, which, of course, yield to those at disposal of neocons, they wage an uncompromising struggle against neocons, levering especially harsh criticism at their approaches to the foreign policy. Continuing the traditions of the American pre-war conservatism, paleocons think that after the defeat of communism, the USA has nothing to do in the international arena and it must focus on its domestic problems. Hence, they are for return of the policy of "isolation." They are very consistent condemning the imperialist aspirations of neocons. And the title of Pat Buchanan's book "A Republic, Not an Empire" is characteristic to it. He thinks that the group of neocons has seized the USA's foreign policy through conspiracy and uses it to fulfill its mad

\section{REFERENCES}

1. Fukuyama, F. (1992). The End of history and the last man. New York: Free Press.

2. Gelernter, D. (2005). "The inventor of modern conservatism". The Weekly Standard, Vol. 010, Issue: 20, 7 February 2005, (pp. 16 - 24).

3. Huntington, S.P. (1996). The Clash of Civilizations and the Remaking of World Order. New York: Simon and Schuster.

4. Joiner, W. (2002). "Paleocons' Revenge", Folio, Sep. 1.

5. Jost, J.T., Glaser, J., Kruglanski, A.W., Sulloway, F.J. (2003). "Political Conservatism as ideas bearing no relations to the reality, hereby endangering the authority and security of this powerful country. Buchanan and other paleocons emphasize that neocons' intolerable approach not only to the countries declared enemies, but also to its West-European allies, leads to the USA's real isolation. Last year paleocons organized a campaign in the press in favor of restoration of allied relations with France, hereby trying to soften the tense relations with that country aggravated due to the tough anti-French position of neocons.

In conclusion, it should be noted that dissatisfaction with the policy of neocons has become widespread in the US. This obviously leads to the weakening of positions of conservatism as a concept of world perception among the circles of American political and intellectual elite.

Motivated Social Cognition". Psychological Bulletin, Vol. 129, №. 3, (p. 339 - 375).

6. Kekes, J. (1997). "What Is Conservatism?" Philosophy, Vol. 72, №. 281, July. (pp. 351374).

7. Kirk, R. "Ten Conservative Principles", Russell Kirk Center, http://www.kirkcenter. org/index.php/detail/ten-conservativeprinciples/.

8. Waligorski, C.P. (1990). The Political theory of conservative economics. Kansas: University Press of Kansas.

9. Zeiger, H. (2003). "The definition of conservatism and the language of political identity". Renew America, January. 


\section{MODERN CONSERVATISM AS A WORLD PERCEPTION AND POLITICAL}

MOVEMENT: THE CASE OF AMERICAN NEOCONS AND PALEOCONS

\section{SUMMARY}

The article deals with the problems of modern conservatism. Author offers a two-level analysis of maim principles of this wide spread in our times political and social philosophical trend. The first one is based on its interpretation as a world perception of conservative way thinking person. The second considers conservatism political movement and investigates some important peculia- rities of polities of neocons and paleocons, which are the main groupings of contemporary conservatisms in USA.

Key concepts: conservatism, modern, perception, movement, USA, neocons, paleocons.

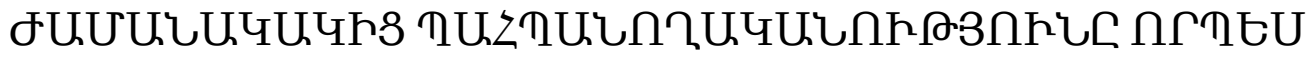

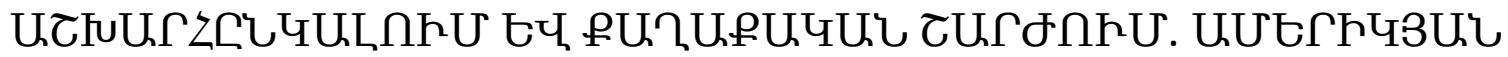

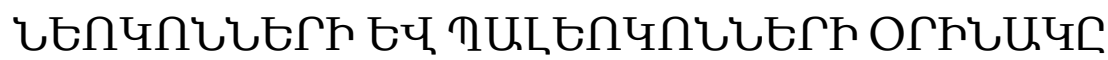

\section{UUФกФПధU}

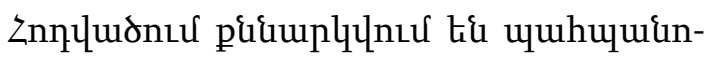

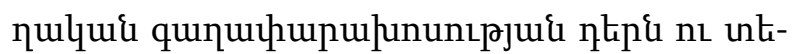

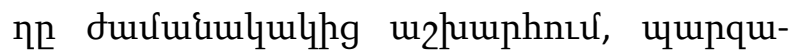

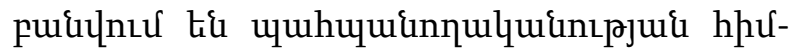

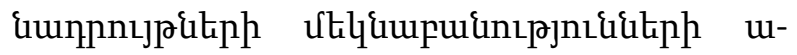

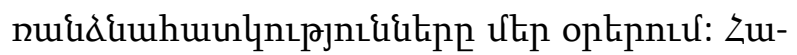

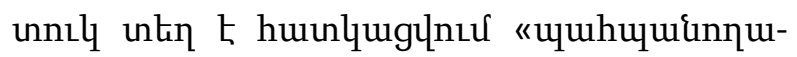

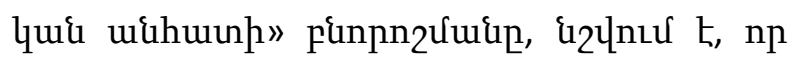

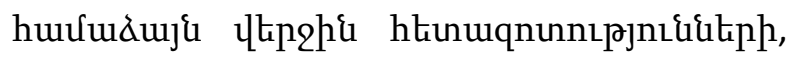

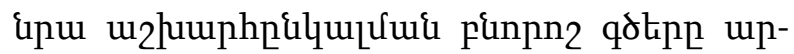

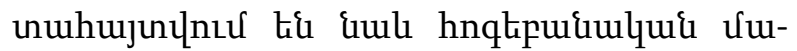
цupnulh Џnu:

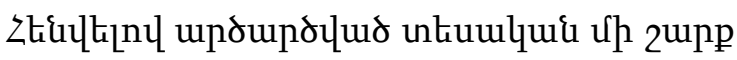

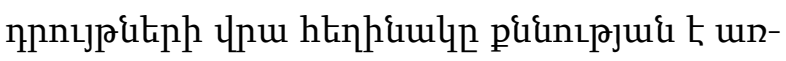

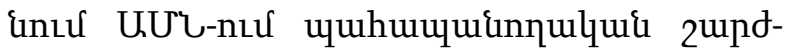

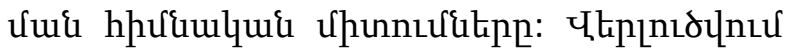

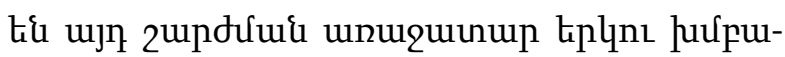

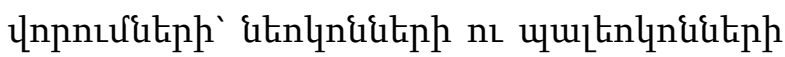

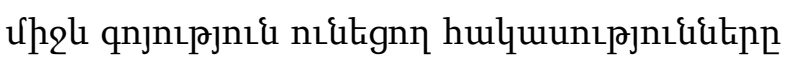

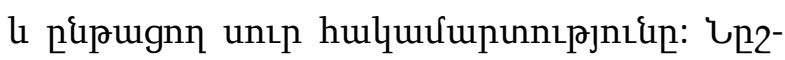

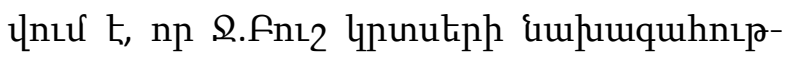

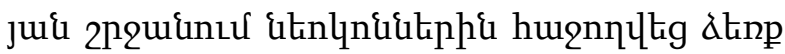

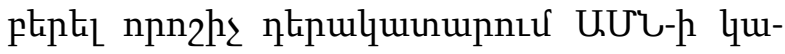

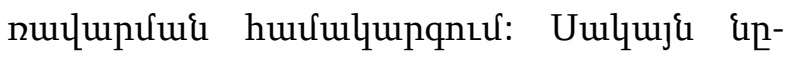

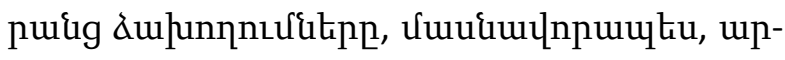




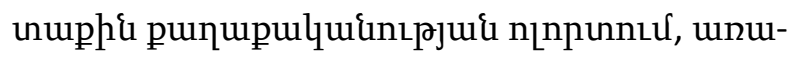

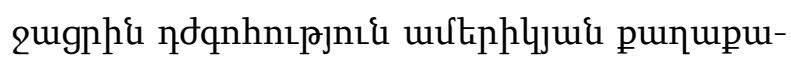

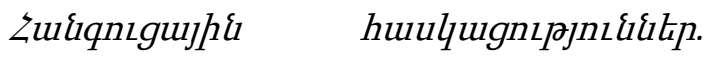

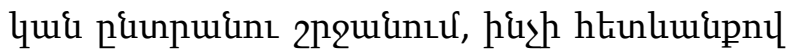

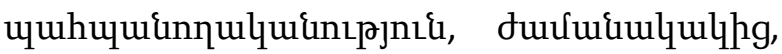

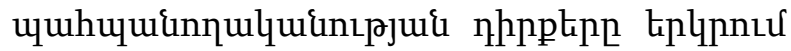
pnţugut:

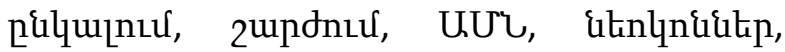
uultinlnisitin: 